\title{
Application of hemin-induced growth and biochemical modifications in Hassawi okra (Abelmoschus esculentus L.) grown in seawater salinity
}

\author{
Osman Ali Hag El Amin ${ }^{1,2^{*}}$, Mohamed Abdel Mohsen El-kersh ${ }^{1,3}$, Mohamed Mahgoub Azooz ${ }^{1,4}$ \\ ${ }^{1}$ Biological Sciences Department, College of Science, P.O. Box 5324 - 31982, King Faisal University, Saudi Arabia \\ ${ }^{2}$ Botany Department, Faculty of Science, University of Khartoum, Khartoum, Sudan \\ ${ }^{3}$ Department of Biochemistry, Faculty of Science, Alexandria University, Alexandria, Egypt \\ ${ }^{4}$ Botany Department, Faculty of Science, South Valley University, 83523 Qena, Egypt
}

\author{
*Corresponding author: oelamin@kfu.edu.sa
}

\section{Abstract}

The present study investigated the possible protective role of hemin $(75 \mu \mathrm{M})$ on okra (Abelmoschus esculentus L.) plants grown under diluted seawater (seawater/normal water) in plastic bags on loam soil and compost (1:1). Four levels of seawater were prepared by diluting seawater to give $1.8,3.6,5.4$ and $7.2 \mathrm{dsm}^{-1}$. Okra plants were irrigated with these concentrations of seawater. The effects of seawater salinity on okra plants were evaluated by determining growth parameters, superoxide dismutase (SOD) activity, catalase (CAT) activity ascrobate content, $\alpha$-amylase, protease and lipid peroxidation in the presence or absence of hemin. The study found that seawater salinity resulted in a high level of lipid peroxidation, which was associated with significant decrease in growth parameters and protease activity. The activity of SOD, CAT and ascorbate content were increased significantly, compared to control plants. Alleviation effect of hemin was obvious on growth parameters at most salinity levels. This was associated by enhancement of CAT and $\alpha$-amylase activities and reduction of lipid peroxidation compared to the corresponding untreated salinized plants. So hemin could play a central function as a signal molecule in salt tolerance of okra plants. The results of this study demonstrated that okra can be grown successfully using diluted seawater and the different antioxidants could partially alleviate the harmful effects of seawater stress that reflected on growth and some physiological changes of okra plant. According to these findings, it can be pronounced that the treatment of salinized okra with hemin $(75 \mu \mathrm{M})$ may reduce the negative impact of light salinity stress.

Keywords: Abelmoschus esculentus L.; antioxdant enzymes; $\alpha$-amylase; seawater salinity.

Abbreviations: ASA_ascorbate; CAT_catalase; hydrogen peroxide_ $\mathrm{H}_{2} \mathrm{O}_{2} ; \cdot \mathrm{OH}_{-}$hydroxyl radical; MDA_malondialdehyde; ROS_reactive oxygen species; $S O D \_s u p e r o x i d e$ dismutase, $02 \bullet$ superoxide.

\section{Introduction}

Currently, salinity is an increasing problem in coastal and agricultural areas causing a critical reduction in plant productivity and yield. Higher salinity concentrations decrease stem and root lengths, fresh weight (Mohammadi et al., 2018). One of the first observable responses after salinity imposition is the reduction in shoot growth (Negrao et al., 2017). Plants exposure to salt stress enhanced the production of reactive oxygen species (ROS) such as hydrogen peroxide $\left(\mathrm{H}_{2} \mathrm{O}_{2}\right)$, superoxide $\left(\mathrm{O}_{2}{ }^{-}\right)$, singlet oxygen $\left({ }^{1} \mathrm{O}_{2}\right)$ ) and hydroxyl radical $\left(\mathrm{OH}^{-}\right)$(Ahanger et al., 2017; Arora et al. 2019). ROS causes major cellular damage represented in protein degradation, enzymes inactivation and lipid peroxidation (Pitzschke et al., 2006; Jamil et al., 2012; Zhou et al., 2017). Plants evolved various mechanisms to protect the cellular toxic oxidative stresses and maintain them at low levels (Choudhury et al., 2017; Serkedjieva, 2011) by ROS scavenging enzymes as superoxide dismutase, catalase and ascorbate peroxidase as well as non-enzymatic action such as ascorbate. The superoxide dismutase (SOD) is the first line of defense against ROS (Alscher et al., 2002), and the activity of SOD is an indication for salt tolerance and could be considered as criteria for tolerance selection (Hefny and Abdel-Kader, 2007). SOD plays a vital role in protecting cells from oxidative damage, by catalyzing the conversion of $\mathrm{O}_{2}^{-}$to $\mathrm{H}_{2} \mathrm{O}_{2}$ and $\mathrm{H}_{2} \mathrm{O}$ (Moran et al., 2003). The produced $\mathrm{H}_{2} \mathrm{O}_{2}$ is toxic to cells and has to be further detoxified by the highly active catalase enzyme to water and oxygen (Demidchik, 2015). The activities of CAT and SOD increased with the increasing salinity (Noreen and Ashraf, 2009; Temizgul et al., 2016). Ascorbate peroxidase has vital defensive role against ROS and can catalyze the breakdown of $\mathrm{H}_{2} \mathrm{O}_{2}$ that is produced by SOD (Apel and Hirt, 2004). The ascending activity of antioxidant enzyme ameliorated salt resistance (Temizgul et al., 2016).

Ascorbate (ASA) is a major non-enzymatic antioxidant and plays a crucial role in plant growth processes, cell division and cell wall extension (Conkin, 2001; Pastori et al., 2003; Nunes et al., 2019). The level of ASA in plants responded 
directly to salinity stress and consequently plays an important role in mitigation of salinity stress (Zhang et al., 2011; Azooz, 2013; Lotfy et al., 2019). However, plants with high ascorbate concentration showed salt tolerance potentials with less lipid peroxidation, high fresh weight and root length (Azooz and Al-Fredan, 2009; Zhang et al., 2011). Huang et al. (2005) detected an increase of ascorbate contents in Arabidopsis after salt treatment. On the other hand, the activity of $\alpha$-amylase and protease decreased with the increasing salinity (Ashraf et al., 2002). Malondialdehde (MDA) is a reactive aldehyde produced due to the degradation of polyunsaturated lipids by ROS. As well as MDA cause toxic stress in cells and form advanced lipoxidation products. Moreover, MDA is a useful indicator for the cellular stress in animals and plants (El-Beltagi and Mohamed, 2013; Kong et al., 2016).

The commercial hemin is actually ferriprotoporphyrin IX, which is also the prosthetic moiety for a large number of proteins that play essential roles in the transport of oxygen, mitochondrial functions, and a variety of signal transduction in both animals and plants (Conroy et al., 1982; Suzuki et al., 1995). Additionally, ferriprotoporphyrin IX and its derivatives are related to the synthesis of chlorophyll as well as phytochrome chromophore, where a ferrochelatase catalyzes heme formation by the insertion of $\mathrm{Fe}^{2+}$ into the protoporphyrin IX nucleus (Shekhawat and Verma, 2010). It was further known that hemin up-regulates heme oxygenase- $1\left(\mathrm{HO}^{-1}\right)$, an intracellular enzyme that catalyzes the initial and rate-limiting step in the oxidative degradation of heme, and generates biliverdin (BV), free iron $\left(\mathrm{Fe}^{2+}\right)$, and carbon monoxide (CO) (Ryter et al., 2002; Devadas and Dhawan, 2006). Some investigations of the functional roles of hemin and $\mathrm{HO} / \mathrm{CO}$ system in plants, including the hormone-like effects on adventitious root and lateral root formation (Cao et al., 2011) and the protection against salinity stress (Xie et al., 2011). Carbon monoxide and $\mathrm{NaCl}$ solution, when were present together, greatly promoted germination process by promoting the activities of amylase in wheat (Xu et al., 2006).

Application of $\beta$-cyclodextrin-hemin complex treatments enhanced cucumber adventitious root formation (Lin et al., 2012). Similar results were obtained by Li et al. (2015) while Fu et al. (2011) detected amelioration of toxic effect of cadmium by hemin treatments. Jin et al. (2013) concluded that alfalfa plants displayed enhanced tolerance to oxidative stress induced by parquet- herbicide when treated with hemin. This enhancement was exhibited by alleviation of the inhibition of root growth, reduced lipid peroxidation and the decreased hydrogen peroxide and superoxide anion radical levels. The activities and transcripts of antioxidant enzymes were induced after exposure to hemin. Hemin mitigated the effect of salt stress on plant height, fresh and dry weight of plants, succulence and leaf area and the mitigation enhanced with the increase of hemin concentrations (Abd El-Monem et al., 2013). However, the increasing soil and water salinity is the most important constraint that faces crop production in Al-Ahassa region. The cultivated soil of Al-Ahassa is highly saline due to irrigation by highly saline water in addition to the shallow ground water table (AlBarrak, 1997). One of the very successful crops that widely cultivated in Al-Ahassa is the locally famous Hassawi okra (Albamia Alhasawia). The okra plant is sensitive to salinity especially in the early stage of its growth (Habib et al., 2016).
Okra (Abelmoschus esculentus L.) belongs to the family malvaceae and it is annual, often cross-pollinated vegetable of tropical and subtropical regions. This study investigated the effects of $1.8,3.6,5.4$ and $7.2 \mathrm{dsm}^{-1}$ seawater salinity levels with or without hemin treatment on okra plants to enrich the capacity of okra research and improve the understanding the knowledge on use of hemin for amelioration of salinity effect on growth and quality of okra plants, irrigated with different saline levels. However, the information of okra plants and foliar application of hemin and its effect on the tolerance to saline stress needs further studies. Thus, studies that allow for the utilization of hemin in okra acclimation to saline stress become important for its full development in the semi-arid region of Saudi Arabia. Thus, further studies need to be performed to evaluate the effects of exogenous application of hemin on the growth and some physiological changes of okra plants irrigated with seawater with different saline levels

\section{Results and discussion}

\section{Effect of seawater stress and foliar application with hemin on growth parameters}

Data exhibited in Table 1 indicated that salinity stress reduced sharply shoot length, root length, fresh weight and dry weight of okra plants. However, a highly significant alleviation was shown in shoot length (53.31\%) and dry weight $(139.13 \%)$ when treatment with hemin at the lower salinity level $\left(1.8 \mathrm{dsm}^{-1}\right)$ compared to corresponding salinized plants. After that, hemin application caused insignificant increase in shoot length, root length, fresh weight, and dry weight of okra plants compared to salinized okra plants. When plants are exposed to high salinity conditions, water stress occurs (Akrami and Arzani, 2018). Salinity causes critical plant cell injuries, less chlorophyll content and less mineral uptake leading to altered photosynthesis efficiency and retarded growth (Yeo, 1998; Carter et al., 2005). Similar stress complications were also found in the present study represented by significant reduction in shoot length, root length, fresh and dry weights after treatment with salinity for 6 weeks. The osmotic effect resulting from soil salinity may cause disturbances in the water balance of the plant (Saffan, 2008), including a reduction of turgor and inhibition of growth. At the whole plant level the effect of stress is usually perceived as a decrease in photosynthesis and growth (Rahdari and Hoseini, 2012), and is associated with alteration in carbon and nitrogen metabolism (Yordanov et al., 2003). The result confirmed opinions of others (Simzu et al., 2008; Fu et al., 2011; Abd El-Monem et al., 2013) who detected hemin amelioration of stress toxicity at least at low salinity concentration.

\section{Effect of seawater stress and foliar application with hemin on some antioxidant enzymes activities and ascorbate content}

The activity of superoxide dismutase was increased with the increase of seawater salinity from 10.18 at $1.8 \mathrm{dsm}^{-1}$ salinity (the lowest level) to $12.08 \mathrm{nmol} / \mathrm{min} / \mathrm{ml}$ at $7.2 \mathrm{dsm}^{-1}$ salinity (the highest level) than control $(9.11 \mathrm{nmol} / \mathrm{min} / \mathrm{ml})($ Table 2). At treatment with hemin, SOD activity had a non- 
Table 1. Effect of seawater salinity $\left(\mathrm{dsm}^{-1}\right)$ and hemin $(75 \mu \mathrm{M})$ on root length $(\mathrm{cm})$, shoot length $(\mathrm{cm})$, fresh weight $(\mathrm{g} / \mathrm{plant})$ and dry weight (g/plant) of okra plants. Values are means of three replicates. \pm Standard deviation (SD). Statistical significance of differences compared to control: significant at $\mathrm{P}<0.05$; ** significant at $\mathrm{P}<0.01$.

\begin{tabular}{llllll}
\hline Treatments & $\begin{array}{l}\text { Seawater } \\
\text { salinity levels } \\
\left.(\mathrm{dsm})^{-1}\right)\end{array}$ & $\begin{array}{l}\text { Root Length } \\
(\mathrm{cm})\end{array}$ & $\begin{array}{l}\text { Shoot length } \\
(\mathrm{cm})\end{array}$ & $\begin{array}{l}\text { Fresh weight } \\
(\mathrm{g} / \mathrm{plant})\end{array}$ & $\begin{array}{l}\text { Dry weight } \\
\text { (g/plant) }\end{array}$ \\
\hline Control & 0.0 & $23.32 \pm 0.64$ & $24.26 \pm 1.77$ & $11.80 \pm 1.85$ & $1.07 \pm 0.08$ \\
& 1.8 & $19.10 \pm 2.75$ & $13.41 \pm 0.62^{* *}$ & $2.22 \pm 0.69^{* *}$ & $0.23 \pm 0.02^{* *}$ \\
Without & 3.6 & $12.64 \pm 1.52^{* *}$ & $12.66 \pm 1.65^{* *}$ & $1.25 \pm 0.24^{* *}$ & $0.22 \pm 0.06^{* *}$ \\
hemin & 5.4 & $12.04 \pm 0.07^{* *}$ & $12.19 \pm 2.09^{* *}$ & $0.88 \pm 0.18^{* *}$ & $0.21 \pm 0.02^{* *}$ \\
& 7.2 & $11.41 \pm 0.61^{* *}$ & $8.27 \pm 1.95^{* *}$ & $0.64 \pm 0.13^{* *}$ & $0.05 \pm 0.01^{* *}$ \\
With & 0.0 & $27.56 \pm 7.36$ & $29.86 \pm 0.93^{* *}$ & $14.97 \pm 2.01^{* *}$ & $1.58 \pm 0.07^{* *}$ \\
hemin $(75 \mu \mathrm{M})$ & 1.8 & $22.51 \pm 1.94$ & $20.56 \pm 1.93^{* *}$ & $2.51 \pm 0.33^{* *}$ & $0.55 \pm 0.04^{* *}$ \\
& 3.6 & $14.42 \pm 2.57^{* *}$ & $14.05 \pm 0.61^{* *}$ & $1.57 \pm 0.61^{* *}$ & $0.24 \pm 0.06^{* *}$ \\
\hline LSD 5\% & 5.4 & $13.97 \pm 0.15^{* *}$ & $12.71 \pm 0.89^{* *}$ & $0.94 \pm 0.18^{* *}$ & $0.22 \pm 0.02^{* *}$ \\
LSD 1\% & 7.2 & $11.57 \pm 1.42^{* *}$ & $8.19 \pm 0.42^{* *}$ & $0.70 \pm 0.01^{* *}$ & $0.05 \pm 0.02^{* *}$ \\
\hline
\end{tabular}

Table 2. Effect of Gulf water salinity $\left(\mathrm{dsm}^{-1}\right)$ and hemin $(75 \mu \mathrm{M})$ on superoxide dismutase activity $(\mathrm{nmol} / \mathrm{min} / \mathrm{ml})$, catalase activity $(\mathrm{nmol} / \mathrm{min} / \mathrm{ml})$ and ascrobate $(\mu \mathrm{M} \mathrm{HCHO} / \mu \mathrm{g}$ protein) of okra plants. Values are means of three replicates. \pm Standard deviation (SD).Statistical significance of differences compared to control: significant at $\mathrm{P}<0.05$; ${ }^{* *}$ significant at $<001$.

\begin{tabular}{lllll}
\hline Treatments & $\begin{array}{l}\text { Seawater } \\
\text { salinity levels } \\
(\mathrm{dsm})^{-1}\end{array}$ & $\begin{array}{l}\text { Superoxide dismutase } \\
\text { activity }(\mathrm{nmol} / \mathrm{min} / \mathrm{ml})\end{array}$ & $\begin{array}{l}\text { Catalase activity } \\
(\mathrm{nmol} / \mathrm{min} / \mathrm{ml})\end{array}$ & $\begin{array}{l}\text { Ascrobate }(\mu \mathrm{M} \\
\text { CHO/ } \mu \mathrm{g} \text { protein) }\end{array}$ \\
\hline Control & 0.0 & $9.11 \pm 1.07$ & $18.39 \pm 0.30$ & $577.00 \pm 10.02$ \\
& 1.8 & $10.18 \pm 1.05$ & $36.20 \pm 1.80^{* *}$ & $580.48 \pm 19.49$ \\
Without hemin & 3.6 & $10.44 \pm 0.46$ & $39.30 \pm 1.70^{* *}$ & $635.75 \pm 4.99^{* *}$ \\
& 5.4 & $11.65 \pm 0.39^{* *}$ & $48.85 \pm 1.13^{* *}$ & $1337.92 \pm 19.25^{* *}$ \\
& 7.2 & $12.08 \pm 1.92^{* *}$ & $39.92 \pm 0.98^{* *}$ & $1033.00 \pm 21.52^{* *}$ \\
With & 0.0 & $10.54 \pm 0.54$ & $22.83 \pm 1.19^{* *}$ & $709.33 \pm 10.69^{* *}$ \\
hemin $(75 \mu \mathrm{M})$ & 1.8 & $11.20 \pm 0.10^{* *}$ & $36.68 \pm 0.32^{* *}$ & $596.81 \pm 8.90$ \\
& 3.6 & $10.20 \pm 0.20$ & $62.42 \pm 1.58^{* *}$ & $654.46 \pm 9.60^{* *}$ \\
LSD 5\% & 5.4 & $10.53 \pm 0.53$ & $59.73 \pm 1.34^{* *}$ & $1334.85 \pm 9.95^{* *}$ \\
LSD 1\% & 7.2 & $12.07 \pm 1.94^{* *}$ & $46.84 \pm 1.08^{* *}$ & $1074.68 \pm 72.67^{* *}$ \\
\hline
\end{tabular}

Table 3. Effect of Gulf water salinity at $\mathrm{P}<0.05$.; **significant at $\mathrm{P}<001$ on Protease ( $\mu \mathrm{mol}$ tyr/ $\mathrm{mg}$ protein), $\alpha$-amylase ( $\mathrm{mg}$ $\mathrm{starch} / \mathrm{min}$ ) and Malodialdehyde ( $\mu \mathrm{mol} / \mathrm{g}$ fresh weight) of okra plants. Values are means of three replicates. \pm Standard deviation (SD). Statistical significance of differences compared to control: significant at $\mathrm{P}<0.05$; $* *$ significant at $\mathrm{P}<001$.

\begin{tabular}{lclll}
\hline Treatments & $\begin{array}{l}\text { Seawater } \\
\text { salinity levels } \\
\left(\mathrm{dsm}^{-1}\right)\end{array}$ & $\begin{array}{l}\text { Protease } \\
(\mu \mathrm{mol} \text { tyr/mg } \\
\text { protein) }\end{array}$ & $\begin{array}{l}\alpha \text {-amylase } \\
(\mathrm{mg} \text { starch/min) }\end{array}$ & $\begin{array}{l}\text { Malodialdehyde was } \\
(\mu \mathrm{mol} / \mathrm{g} \text { fresh weight) }\end{array}$ \\
\hline Control & 0.0 & $1.48 \pm 0.11$ & $1.81 \pm 0.29$ & $1.19 \pm 0.20$ \\
Without & 1.8 & $1.23 \pm 0.23$ & $1.96 \pm 0.14$ & $1.36 \pm 0.35$ \\
hemin & 3.6 & $0.96 \pm 0.16^{* *}$ & $1.67 \pm 0.26$ & $1.47 \pm 0.07$ \\
& 5.4 & $1.10 \pm 0.08^{* *}$ & $1.44 \pm 0.23$ & $1.47 \pm 0.11$ \\
& 7.2 & $0.91 \pm 0.21^{* *}$ & $1.45 \pm 0.08$ & $1.17 \pm 0.16$ \\
With & 0.0 & $1.11 \pm 0.10^{* *}$ & $1.73 \pm 0.13$ & $1.27 \pm 0.18$ \\
hemin $(75 \mu \mathrm{M})$ & 1.8 & $1.26 \pm 0.20$ & $2.30 \pm 0.30^{*}$ & $1.29 \pm 0.11$ \\
& 3.6 & $0.85 \pm 0.17^{* *}$ & $2.07 \pm 0.22$ & $1.28 \pm 0.31$ \\
\hline LSD 5\% & 5.4 & $0.80 \pm 0.01^{* *}$ & $1.89 \pm 0.29$ & $1.14 \pm 0.13$ \\
LSD 1\% & 7.2 & $0.83 \pm 0.15^{* *}$ & $1.78 \pm 0.19$ & 0.34 \\
\hline
\end{tabular}


significant change compared with the corresponding salinized levels. The changes in catalase (CAT) activity in response to treatment with salinity and/or hemin are illustrated in Table 2. Salinity showed a highly significant increase in CAT activity at all seawater salinity used. Foliar application of hemin strengthened and increased the activity of CAT enzyme when compared to seawater salinity treatments alone.

Data presented in Table 2 showed that seawater salinity and/or hemin have positive impacts on ascorbate content in okra plant. The increase in ascorbate was highly significant in all treatments, since the maximum increase arrived $131.7 \%$ at $5.4 \mathrm{dsm}^{-1}$ salinity than control.

The activity of defense enzymes SOD and CAT in our study exhibited increase with the increasing salinity level. These results have been reported (Temizgul et al. 2016; Trevizan et al., 2019). Other evidences have shown that hemin could prevent oxidative injury. Accordingly, our results showed that hemin treatment caused enhancement in activity of CAT at most seawater salinity levels. However, the effect of hemin on SOD activity was inconspicuous. For ascorbate, the improvement in its content was highly significant at all salinity levels. Nunes et al. (2019) showed that ascorbic acid at concentrations of $0.50 \mathrm{mM}$ allowed the development of more vigorous seedlings and the reduction of membrane damage caused by oxidative stress in cowpea plants. These results support the reports of Lin et al. (2012) in cucumber, and Li et al. (2015) in tomato that used hemin to generate considerable enhancement of tolerance against stress toxicity. Xu et al. 2011 reported that hemin could increase the activity of antioxidant enzymes, including superoxide dismutase (SOD), catalase (CAT), and ascorbate peroxidase (APX), consequently resulting in the alleviation of oxidative injury caused by salinity stress. It could be concluded that hemin could reinforce the $\mathrm{HO}$ expression conferred by seawater stress, which could be regarded as a mechanism of cell protection against oxidative damage.

\section{Effect of seawater stress and foliar application with hemin on protease activity, $\alpha$-amylase activity and malondialdehyde concentration}

The results in Table 3 showed that protease activity significantly decreased in plants grown under salinity in absence or presence of hemin compared to the control. While, $\alpha$ - amylase activity increased to maximum $1.96 \mathrm{mg}$ starch/min at $1.8 \mathrm{dsm}^{-1}$ against the control, and then decreased with the increase of seawater salinity. Application of hemin increased $\alpha$-amylase activity compared to the corresponding plants treated with seawater salinity levels only. The reduction in $\alpha$-amylase and protease activities with the increasing of salinity levels in the present work were in harmony with the other reports which showed similar results (Ogra and Baija, 1982; Ashraf et al., 2002). Significant enhancement for $\alpha$-amylase activity was exerted by hemin compared to the corresponding untreated salinized plants. This attributed to that hemin could significantly reduce the inhibition of seed germination and then seedling growth and enhance amylase activity, therefore accelerating the formation of reducing sugar and total soluble sugar ( $\mathrm{Xu}$ et al., 2011). The previous studies showed that, hemin and $\mathrm{NaCl}$ solution, when were present together, greatly promoted germination process by enhancing the activities of amylase in wheat (Xu et al. 2006) and rice seeds (Liu et al. 2007) The results in (Table 3 ) showed a gradual increase in malondialdehyde (MDA) concentration with the increase of seawater salinity. Conversely, when treatment with hemin, MDA decreased compared to the corresponding heminuntreated salinized plants. However, there are a highly significant decrease in MDA at $7.2 \mathrm{dsm}^{-1}$. MDA is a useful indicator of stress in plants (El-Beltagi and Mohammed, 2013; Kong et al., 2016). In the present study, MDA concentration was directly proportional to salinity concentrations. It showed a gradual significant increase with increasing seawater levels compared to control.. The significant increase of MDA in plants, exposed to seawater stress indicated that increase of lipid peroxidation in salinized plants led to disorder of plasmatic membranes, resulting in increase of MDA content. Free radicals produced by salinity stress enhanced lipid peroxidation and protein degradation (Pitzschk et al., 2006). Foliar spraying of okra with hemin, as shown by results ameliorated production of reactive aldehyde (MDA) and enhances salinity tolerance especially at the lower salinity level.

\section{Materials and Methods}

\section{Plant materials and growth conditions}

Albamia Alhasawia (okra) seeds were grown on plastic bags containing approximately $10 \mathrm{~kg}$ of air-dried loam soil and compost (1:1). The bags were fitted with holes in the bottom for drainage surplus liquid. The study was conducted in plastic greenhouse in Hofouf, Saudi Arabia. The seawater used for irrigation in this study was brought from Arabian Gulf at Augare area, $40 \mathrm{~km}$ from Hofuf. Salinity of seawater estimated to be $57 \mathrm{~g} / \mathrm{L}$ (John et al. 1990) equal to 441.47 $\mathrm{mmol} / \mathrm{L}$. Distilled water was used to dilute seawater to four levels of EC (00 (control), 1.8, 3.6, 5.4and $7.2 \mathrm{dsm}^{-1}$ ). Three groups of okra seeds were used. In the first group, the okra seeds were grown in $1.8,3.6,5.4$ or $7.2 \mathrm{dsm}^{-1}$ seawater salinity. The seeds in the second group were grown in the same seawater concentrations and treated with hemin (75 $\mu \mathrm{M})$ as foliar spraying every three days (starting from the $3^{\text {rd }}$ week). The third group was the control and was grown in distilled water. Hemin (Hemin, from bovine, $\geq 90 \%$, SigmaAldrich) $(75 \mu \mathrm{M})$ was prepared by dissolving $0.489 \mathrm{~g}$ of hemin in $0.5 \mathrm{ml}$ of $1 \mathrm{M}$ sodium hydroxide and completed to $1 \mathrm{~L}$ by distilled water. Shoot length, root length, fresh weight and dry weight were measured at $6^{\text {th }}$ week. For fresh weight harvested plants were rinsed with distilled water, dried with papers and weighed. Plant material was dried at $80 \circ \mathrm{C}$ to dry constant weight in an aerated oven. Leaves were collected on weeks six for biochemical analysis.

\section{Assays of some antioxidant enzyme activities, ascorbate and MDA}

\section{Extraction of antioxidant enzymes, ascorbate and MDA}

Okra leaves $(0.5 \mathrm{~g})$ were ground in liquid nitrogen and homogenized in $3 \mathrm{ml}$ of $0.1 \mathrm{M}$ sodium phosphate buffer $\mathrm{pH}$ 7.8 containing $1 \mathrm{mM}$ EDTA, $1 \mathrm{mM}$ phenylmethylsulfonyl fluoride and $20 \mathrm{mg}$ of polyvinylpolypyrrolidone at $4 \mathrm{C}$. . The homogenate was centrifugated at $16000 \mathrm{rpm}$ for $15 \mathrm{~min}$ at $4 \mathrm{C}=$ and the supernatant was immediately made to $40 \%$ 
glycerol. The supernatants were used for determination of SOD and CAT activities and ascorbate as well as MDA and total protein levels.

\section{Assay of some antioxidant enzyme activities and ascorbate content}

\section{Assay of superoxide dismutase activity}

SOD (EC 1.15.1.1), activity was measured according to McMillan-Crowet et al. (1996), and McCord and Fridovich (1969).

\section{Assay of catalase activity}

Catalase (EC 1. 11. 1. 6) assay followed Johansson and Borg (1988). The activity of catalase was estimated by the decrease of absorbance at $240 \mathrm{~nm}$ for $1 \min$ as a consequence of $\mathrm{H}_{2} \mathrm{O}_{2}$ consumption.

SOD and CAT activities and ascorbate level were assayed as described by kits suppliers (Cayman Chemical Company, USA). CAT and ascorbate level was quantified ( $\mu \mathrm{M} \mathrm{HCHO} / \mu \mathrm{g}$ protein) following Vislisel et al. (2007).

\section{Protease (EC 3.4.21.40) activity}

Protease was extracted by homogenizing of $0.3 \mathrm{~g}$ of leaves in $0.1 \mathrm{M}$ Tris- $\mathrm{HCl}, \mathrm{pH} 6.8$ containing $1.0 \mathrm{mM}$ EDTA and $10 \%$ glycerol. Protease activity was determined following the method of Anson (1938) and Lowry et al. (1951) with modifications to suit the microplate procedure. $500 \mu \mathrm{L}$ of $0.65 \%$ casein was added to $100 \mu \mathrm{L}$ of sample homogenate and incubated at $37^{\circ} \mathrm{C}$ for $10 \mathrm{~min}$. The reaction was terminated with addition of $100 \mu \mathrm{L}$ of $110 \mathrm{mM}$ trichloroacetic acid. The mixture was incubated at $37^{\circ} \mathrm{C}$ for $20 \mathrm{~min}$ and centrifuged was at $14000 \mathrm{rpm}$ for $10 \mathrm{~min}$. A volume of $1.25 \mathrm{ml}$ of sodium carbonate $(500 \mathrm{mM})$ was added to $600 \mu \mathrm{L}$ of the supernatant with $250 \mu \mathrm{L}$ of diluted folin reagent $(0.5 \mathrm{M})$. The reaction was read at $660 \mathrm{~nm}$ and the protease activity was determined using tyrosine standard curve ( $\mu \mathrm{mol} \mathrm{tyr} / \mathrm{mg}$ protein).

\section{$\alpha$-amylase (EC 3.2.1.1) activity}

Okra leaves were homogenized in $2.5 \mathrm{ml}$ of $0.075 \mathrm{M}$ sodium phosphate buffer pH 7.25 containing $20 \%(\mathrm{w} / \mathrm{v})$ sucrose that was stored overnight at 4 으 in a polyethylene tube. The extract was centrifuged at $16000 \mathrm{rpm}$ for $10 \mathrm{~min}$. The activity of $\alpha$-amylase was assayed following Chrispeel and Varner (1967). $40 \mu \mathrm{L}$ of sample was mixed with $40 \mu \mathrm{L} 0.2 \%$ starch in Eppendorf tube. The mixture was incubated in water bath at 50 o $\mathrm{C}$ for $30 \mathrm{~min}$. The reaction was stopped by addition of $20 \mu \mathrm{L}$ of $1 \mathrm{M} \mathrm{HCl} .100 \mu \mathrm{L}$ of iodine reagent $(5 \mathrm{mM}$ iodine $+5 \mathrm{mM} \mathrm{KI}$ ). A volume of $150 \mu \mathrm{L}$ of iodine-treated sample was transferred separately to a 96-well transparent flat-bottom plate. The produced blue color absorbance was read at wavelength $580 \mathrm{~nm}$ on a plate reader. A blank was prepared with same procedure using distilled water instead of the sample. The enzyme activity was expressed as $\mathrm{mg}$ $\mathrm{starch} / \mathrm{min}$.

\section{Lipid peroxidation}

Malodialdehyde (MDA) was determined using the method of Peever and Higgins (1989). $600 \mu \mathrm{L}$ of $0.5 \%$ thiobarbituric acid (TBA) in $20 \%$ trichloroacetic acid was added to $100 \mu \mathrm{L}$ of sample loaded on microplate. The mixture was heated at 95 oC for 30 min with shaking. The reaction was quickly cooled in an ice water bath and then centrifuged at $10000 \mathrm{rpm}$ for $10 \mathrm{~min}$. The MDA-TBA complex was read at 532 and $600 \mathrm{~nm}$. The MDA content was calculated using absorption coefficient of $155 \mu \mathrm{mol} / \mathrm{g}$.

\section{Protein contents}

Protein assay was carried out following Ohmishi Barr (1978). Total protein concentration (ug protein/100 ul sample) was calculated from standard curve (standard protein: $100 \mathrm{mg}$ bovine serum albumin (BSA/10 $\mathrm{ml}$ phosphate buffer saline (pH 7.4).

\section{Statistical analysis}

The experiments were designed as completely randomized with three replications. The experimental data were statistically analyzed by ANOVA. Data were compared using the least significant difference (LSD) test at $5 \%\left({ }^{*}\right)$ and $1 \%$ ${ }^{* *}$ ) levels (Snedecor and Cochran, 1980).

\section{Conclusion}

Our results suggest that seawater stress negatively influences the growth of okra plants and encourages the production of ROS. Salinity induces reactive oxygen species ROS producing defensing antioxidant system SOD \& CAT and ascorbate which consequently, would act as a signaling molecule generating antioxidant defenses. Moreover, reactive oxygen species would cause lipid peroxidation. The results of this study demonstrated that okra can be grown successfully using diluted seawater and the different antioxidants could partially alleviate the harmful effects of seawater stress. Hemin could increase the activity of antioxidant enzymes, including superoxide dismutase (SOD) and catalase (CAT), consequently resulting in the alleviation of oxidative injury caused by salinity stress. Contrariwise, the application of hemin could be well used to promote growth at low salt stress and plants innate antioxidant defense potentials especially CAT, thus resulting in the diminution of oxidative damage, as indicated by the decrease of lipid peroxidation.

\section{Acknowledgment}

The authors are grateful to the Deanship of the Scientific Research, King Faisal University, Saudi Arabia for providing financial support for this Project (Grant No. 150148).

\section{References}

Abd El-Monem AA, El-Habbasha SF, Hozayn M (2013) Mitigation salinity stress effects on barley (Hordeum vulgare $\mathrm{L}$.) growth, yield and some physiological aspects by hemin. J Appl Sci Res. 9: 2411- 2421. 
Ahanger MA, Tomar NS, Tittal M, Argal S, Agarwal RM (2017) Plant growth under water/salt stress: ROS production; antioxidants and significance of added potassium under such conditions. Physiol Mol Biol Plants. 23(4): 731-744.

Akrami M, Arzani, A (2018) Physiological alterations due to field salinity stress in melon (Cucumis melo L.). Acta Physiol Plant. 40:1-14.

Al-Barrak S (1997) Characteristics and classification of some costal soils of Al-Ahsa, Saudi Arabia. J King Saud Univ Agric Sci. 9: 319-333.

Alscher RG, Erturk N, Heath LS (2002) Role of superoxide dismutases (SODs) in controlling oxidative stress in plants. J Exp Bot. 53(372):1331-1341.

Anson ML (1938) The estimation of pepsin, trypsin, papain, and cathepsin with hemoglobin. J Gen Physiol. 22(1): 7989.

Apel K, Hirt H (2004) Reactive oxygen species: metabolism, oxidative stress, and signal transduction. Ann Rev Plant Biol. 55: 373-399.

Arora M, Saxena P, Abdin MZ, Varma A (2019) Interaction between Piriformospora indica and Azotobacter chroococcum diminish the effect of salt stress in Artemisia annua L. by enhancing enzymatic and non-enzymatic antioxidants. Symbiosis. 1-13.

Ashraf MY, Afa R, Qureshi MS, Sarwar G, Naqvi MH (2002) Salinity induced changes in s-amylase and protease activities and associated metabolism in cotton varieties during germination and early seedling growth stages. Acta Physiol Plant. 4(1): 37-44.

Azooz MM, Al-Fredan MA (2009) The inductive role of vitamin $C$ and its mode of application on Growth, water status, antioxidant enzyme activities and protein patterns of Vicia faba L. cv. Hassawi grown under seawater irrigation. Amer J plant physiol. 4 (1):38-51.

Azooz MM, El-Zahrani AM, Youssef MM (2013) The potential role of seed priming with ascorbic acid and nicotinamide and their interactions to enhance salt tolerance of Vicia faba L. Aust J Crop Sci. 7 (13):2091-2100

Bowler C, Montagu MV, Inze D (1992) Superoxide dismutases and stress tolerance. Annu Rev Plant Physiol Plant Mol Biol. 43: 83-116.

Cao Z, Geng B, Xu S, Xuan W, Nie L, Shen WB, liang Y, Guan R (2011) BnHO1, a haem oxygenase-1 gene from Brassica napus, is required for salinity and osmotic stress-induced lateral root formation. J Exp Bot. 62:4675-89.

Carter CT, Grieve CM, Poss JA (2005) Salinity effects on emergence, survival, and ion accumulation of Limonium perezi. J Plant Nutrition. 28: 1243-1257.

Choudhury FK, Rivero RM, Blumwald E, Mittler R (2017) Reactive oxygen species, abiotic stress and stress combination. Plant J. 90(5):856-867.

Chrispeel MJ, Varner KE (1967) Gibberellic acid enhanced synthesis and release of alpha-amylase and ribo-nuclease by isolated barley aleurone layers. Plant Physiol. 42: 398406.

Conklin PL (2001) Recent advances in the role and biosynthesis of ascorbic acid in plants. Plant Cell Environ. 24: 383-394.

Conroy JM, Borzelleca DC, McDonell LA (1982) Homology of plant peroxidases: an immunochemical approach. Plant Physiol. 69:28-31.
Demidchik V (2015) Mechanisms of oxidative stress in plants: from classical chemistry to cell biology. Environ Exp Bot. 109:212-228.

Devadas K, Dhawan S (2006) Hemin activation ameliorates HIV-1 infection via heme oxygenase-1 induction. J Immunol. 176:4252-7.

El-Beltagi HS, Mohamed HI (2013) Antioxidative defense mechanism. Not Bot Horti Agrobo. 41(1): 44-57.

Fu G, Zhang L, Cui W, Wang Y, Shen W, Ren Y, Zheng T (2011) Induction of heme oxygenase- 1 with $\beta$-CD-hemin complex mitigates cadmium-induced oxidative damage in the roots of Medicago sativa. Plant and Soil. 345 (1-2): 271-285.

Habib SH, Kausar H, Saud HM (2016) Plant growthpromoting rhizobacteria enhance salinity stress tolerance in okra through ROS-scavenging enzymes," BioMed Res Inter. https://doi.org/10.1155/2016/6284547.

Hefny M, Abdel-Kader DZ (2007) Antioxidant-enzyme system as selection criteria for salt tolerance in forage sorghum genotypes (Sorghum bicolor L. Moench). Inter J Plant Breeding Gene. 1 (2): 38-53.

Huang C, He W, Guo J, Chang X, Su P, Zhang L (2005) Increased sensitivity to salt stress in an ascorbatedeficient Arabidopsis mutant. J Exp Bot. 56:3041-3049.

Jamil M, Bashir S, Anwar S, Bibi S, Bangash A, Ullah F, Rha ES (2012) Effect of salinity on physiological and biochemical characteristics of different varieties of rice. Pak J Bot. 44: 7-13.

Jin Q, Zhu K, Cui W, Xie Y, Han B, Shen W (2013) Hydrogen gas acts as a novel bioactive molecule in enhancing plant tolerance to paraquat-induced oxidative stress via the modulation of heme oxygenase-1 signalling system. Plant Cell Environ. 36: 956-969.

Johansson LH, Borg LA (1988) Spectrophotometric method for determination of catalase activity in small tissue samples. Anal Biochem. 174: $331-336$.

John VC, Coles SL, Abozed Al (1990) Seasonal cycle of temperature, salinity and water masses of the Western Arabian Gulf. Oceanol Acta. 13: 273-281.

Kong W, Liu F, Zhang C, Zhang J, Feng H (2016). Nondestructive determination of Malondialdehyde (MDA) distribution in oilseed rape leaves by laboratory scale NIR hyperspectral imaging. Sci Reports 6:1-8.

Li J, Zhu D, Wang R, Shen W, Guo Y, Ren Y, Shen W, Huang L (2015) $\beta$-Cyclodextrin-hemin complex-induced lateral root formation in tomato: involvement of nitric oxide and heme oxygenase 1. Plant Cell Rep. 34: 381-394.

Lin Y, Li M, Huang L, Shen W, Ren Y (2012) Involvement of heme oxygenase- 1 in $\beta$-cyclodextrin-hemin complexinduced cucumber adventitious rooting process. Plant Cell Rep. 31(9):1563-1572.

Liu HY, Yu X, Cui DY, Sun MH, Sun WN, Tang ZC, Kwak SS, Su WA (2007) The role of water channel proteins and nitric oxide signaling in rice seed germination. Cell Res. 17:638649.

Loutfy N, Azooz MM, Hassanein AM (2), Bassiony A (2019) Potassium synergize the positive effect of ascorbic acid on some morpho-physiological parameters of salt stressed faba bean cultivars. Egypt J Bot. 59 (3): 735-751.

Lowry OH, Rosebrough NJ, Farr AL, Randall RJ (1951) Protein measurement with the Folin phenol reagent. J Bio Chem. 193(1):265-75. 
McCord JM, Fridovich I (1969) An enzymic function for erythrocuprein (hemocuprein). J Biol Chem. 244: 6049 6055.

McMillan-Crow LA, Crow JR, kerby JD (1996) Nitration and inactivation of manganese superoxide dismutase in chronic rejection of human renal allografts. Proc Natl Acad Sci USA. 93: $11853-11858$.

Mohammadi Z, Rastegar S, Abdollahi F, Hosseini Y (2018) Morphological and antioxidant enzymatic activity responses of sapodilla rootstock to salinity stress. J Plant Proc Func. 6: 23-28.

Moran F., James EK, Rubio MC, Sarath G, Klucas RV, Becana $M$ (2003) Functional characterization and expression of a cytosolic iron-superoxide dismutase from cowpea root nodules. Plant Physiol. 133 (2):773-782.

Negrao S, Schmockel SM, Tester M (2017) Evaluating physiological responses of plants to salinity stress. Ann Bot. 119: 1-11.

Noreen Z, Ashraf M (2009) Assessment of variation in antioxidative defense system in salt-treated pea (Pisum sativum) cultivars and its putative use as salinity tolerance markers. J Plant Physiol. 166 (16): 1764-1774.

Nunes, LRL, Pinheiro PR, Cabral FAS, Silva JB, Dutra AS (2019) Ascorbic acid of cowpea seeds under saline stress. J Seed Sci. 41(4):441-451.

Ogra RK, Baijal BD (1982) Physiological studies on the effect of salinity on sorghum. 1 . Changes in alpha-amylase and acid protease during seedling growth. Indian J Plant Physiol. 25 (2): 133-140.

Ohnishi ST, Barr JK (1978) A simplified method of quantitating proteins using the biuret and phenol reagents. Anal Biochem. 86 (1): 193-200.

Pastori GM, Kiddle G, Antoniw J, Bernard S, VeljovicJovanovic S, Verrier PJ, Noctor G, Foyer CH (2003) Leaf vitamin $\mathrm{C}$ contents modulate plant defense transcripts and regulate genes that control development through hormone signaling. Plant Cell. 15:939-951.

Peever TL, Higgins VG (1989) Electrolyte leakage, lipoxygenase and lipid peroxidation induced in tomato leaf tissue by specific and nonspecific elicitors from Cladosporium fluvum. Plant Physiol. 90: 867-875.

Pitzschke A, Forzani C, Hirt H (2006) Reactive oxygen species signaling in plants. Antioxid Redox Sign. 8: 1757-1764.

Rahdari P, Hoseini SM (2012) Drought Stress: A Review. Inter J Agron Plant Prod. 3(10): 443-446.

Ryter SW, Otterbein LE, Morse D, Choi AMK (2002) Heme oxygenase/carbon monoxide signaling pathways: regulation and functional significance. Mol Cell Biochem. 234/235:249-63.

Saffan SE (2008) Effect of salinity and osmotic stresses on some economic plants research. J Agri Biol Sci. 4(2): 159166.
Serkedjieva J (2011) Antioxidant effects of plant polyphenols: a case study of a polyphenol-rich extract from Geranium sanguineum L. In: Gupta SD (ed) Reactive oxygen species and antioxidants in higher plants. $1^{\text {st }}$ edn. Enfield:Science Publishers, New Hampshire. 13.

Shekhawat GS, Verma K (2010) Haem oxygenase (HO): an overlooked enzyme of plant metabolism and defence. J Exp Bot. 61:2255-70.

Shimzu K, Takahashi T, Iwasaki T, Shimizu H, Inoue K, Morimatsu $H$, Omori E, Matsumi M, Akagi R, Hemin MK (2008) Treatment abrogates monocrotaline-induced pulmonary hypertension. Med Chem. 4(6): 572-6.

Snedecor GW, Cochran WG (1980) Statistical Methods. $7^{\text {th }}$ Edition, lowa State University Press, Ames.

Suzuki S, Kassell NF, Lee KS (1995) Hemin activation of an inducible isoform of nitric oxide synthase in vascular smooth-muscle cells. J Neurosurg. 83: 862-6.

Temizgul R, Kaplan M, Kara R, Yilmaz S (2016) Effects of salt concentrations on antioxidant enzyme activity of grain sorghum. Current Trends in Nat Sci. 5 (9): 171-178.

Trevizan1 CB, Bonacina C, Lourenceto L, Santos TB, Souza SGH (2019) Salt stress in popcorn genotypes triggers changes of antioxidant enzymes. Aust J Crop Sci. 3(10):1607-1616

Vislisel JM, Schafer FQ, Buettner GR (2007) A simple and sensitive assay for ascorbate using a plate reader. Anal Biochem. 365 (1): 31-39.

Xie YJ, Xu S, Han B, Wu MZ, Yuan XX, Han Y, et al (2011) Evidence of Arabidopsis salt acclimation induced by upregulation of $\mathrm{HY} 1$ and the regulatory role of Rboh $D$ derived reactive oxygen species synthesis. Plant J. 66:280-92.

Xu S, Lou T, Zhao N, Gao Y (2011) Presoaking with hemin improves salinity tolerance during wheat seed germination. Acta Physiol Plant. 33(4):1173-1183.

Xu S, Sa ZS, Cao ZY, Xuan W, Huang BK, Ling TF, Hu QY, Shen WB (2006) Carbon monoxide alleviates wheat seed germination inhibition and counteracts lipid peroxidation mediated by salinity. J Int Plant Biol. 48: 1168-1176.

Yeo A (1998) Predicting the interaction between the effect of salinity and climate change on crop plants. Sci Hort. 78(1-4):159-174.

Yordanov I, Velikova V, Tsonev T (2003) Plant responses to drought and stress tolerance. Bulg J Plant Physiol. 187-206.

Zhang C, Liu J, Zhang Y, Cai X, Gong P, Zhang J, Wang T, Li H, Ye $Z$ (2011) Overexpression of SIGMEs leads to ascorbate accumulation with enhanced oxidative stress, cold, and salt tolerance in tomato. Plant Cell Rep. 30:389-398.

Zhou C, Busso CA, Yang YG, Zhang Z, Wang ZW, Yang YF, Han XG (2017) Effect of mixed salt stress on malondialdehyde, proteins and antioxidant enzymes of Leymus chinensis in three leaf colors. Inter J Exp Bot. (Fyton) 86: 205-213. 